\title{
Christophe Bourgeois, Théologies poétiques de l'âge baroque. La Muse chrétienne (1570-1630)
}

\section{Daniela Dalla Valle}

\section{(2) OpenEdition}

1 Journals

\section{Edizione digitale}

URL: http://journals.openedition.org/studifrancesi/9176

DOI: 10.4000/studifrancesi.9176

ISSN: 2421-5856

\section{Editore}

Rosenberg \& Sellier

\section{Edizione cartacea}

Data di pubblicazione: 1 juin 2008

Paginazione: 177-178

ISSN: 0039-2944

\section{Notizia bibliografica digitale}

Daniela Dalla Valle, «Christophe Bourgeois, Théologies poétiques de l'âge baroque. La Muse chrétienne (1570-1630)», Studi Francesi [Online], 154 (LII | I) | 2008, online dal 30 novembre 2015, consultato il 14 janvier 2021. URL: http://journals.openedition.org/studifrancesi/9176 ; DOI: https://doi.org/10.4000/ studifrancesi.9176

Questo documento è stato generato automaticamente il 14 janvier 2021.

\section{(c) 9 (i) $\Theta$}

Studi Francesi è distribuita con Licenza Creative Commons Attribuzione - Non commerciale - Non opere derivate 4.0 Internazionale. 


\title{
Christophe Bourgeois, Théologies poétiques de l'âge baroque. La Muse chrétienne (1570-1630)
}

\author{
Daniela Dalla Valle
}

\section{NOTIZIA}

CHRISTOPHE BOURGEOIS, Théologies poétiques de l'âge baroque. La Muse chrétienne (1570-1630),

Paris, Champion, 2006, pp. 851.

1 È veramente un bel libro su una parte dell'età barocca - definizione, questa, ormai un po' svalutata negli studi francesi -, impostato su alcune intuizioni famose di Jean Rousset (citato frequentemente ed inserito in una bibliografia molto ricca e diversificata).

2 L'A. si propone di analizzare, definire, confrontare la letteratura barocca cristiana francese, cercando di far emergere il risultato del confronto fra poetiche barocche e teologie cristiane - cattoliche o protestanti. Molti autori, già molto noti, sono ripresi e nuovamente analizzati (La Ceppède, Sponde, d'Aubigné); altri, se non ignorati almeno poco studiati, emergono da questa nuova lettura (Pierre de Croix, Hopil...).

Il volume è suddiviso in quattro parti: la prima s'intitola «La conversion des muses», e studia come avvenne il passaggio dalle muse profane alle muse cristiane. La seconda si sofferma sulle figure della Bibbia, come fonti e come oggetto di commenti. La terza studia la retorica delle anime: modello devoto, silenzio mistico, poesia e spiritualità calviniste. La quarta parte suggerisce, invece, delle prospettive: passa dallo studio di veemenza e dolcezza a quello di veemenza ed eccesso e di veemenza e passioni, colti in vari autori, per concludersi riproponendo l'esistenza di una mistica della parola, a cui partecipa largamente la poesia religiosa. 